\title{
ANALISIS PENERIMAAN SISTEM INFORMASI DAN TEKNOLOGI DALAM PENINGKATAN PELAYANAN DIGITAL LIBRARY DI JURUSAN EKONOMI SYARIAH FAKULTAS EKONOMI DAN BISNIS ISLAM INSTITUT AGAMA ISLAM NEGERI TULUNGAGUNG
}

\author{
Oleh \\ Nur Aziz Muslim(1), Bambang Triyono ${ }^{2)}$ \\ Institut Agama Islam Negeri Tulungagung ${ }^{1)}$ \\ Institut Agama Islam Negeri Salatiga ${ }^{2)}$
}

\begin{abstract}
The research objective includes the content and formulation of research problems. The purpose of this study is a) to determine the effect of the reception of information systems and technology models in improving digital library services in the department of Islamic economics, Faculty of Economics and Business, Islamic Institute of Islamic Affairs, Tulungagung. b) Produce an acceptance model of information systems and technologies developed to improve the ease of student services. c) Describe the weaknesses found in the information system acceptance model and the technology that has been produced.

Path coefficient analysis aims to see the significance of the path coefficient (regression weights estimate) to prove the effect. In the two-way test (two tailed), the results of the significant influence if the significance level of 0.05 value of the critical ratio $>1.96$ and with a significance level of 0.01 the value of the critical ratio $>2.58$. The suitability of the direction of the path relationship with the direction of the previously hypothesized relationship is also noted, if the direction of the relationship (positive or negative) in accordance with the critical ratio value also meets the requirements, it can be said that the influence of the tested variable has strong support. So it is possible with the existence of educational facilities it will be able to improve learning technology.
\end{abstract}

Keywords: technology aceptance model, digital library

\section{PENDAHULUAN}

Kemudahan mahasiswa untuk memanfaatkan layanan digital library dipengaruhi oleh beberapa faktor, salah satu faktor tersebut adalah kemudahan fasilitas dalam memanfaatkan teknologi melalui sistem informasi, sehingga mahasiswa dapat melakukan kegiatan pembelajaran melalui pemanfaatan teknologi. Sistem tersebut memberikan manfaat (usefulness) dan mudah digunakan (ease of 
use). Semakin mudah teknologi dan sistem informasi itu digunakan, maka teknologi dan sistem informasi tersebut dirasa akan manfaat dan kegunaanya.

IAIN Tulungagung merupakan salah satu kampus negeri yang ada di kabupaten Tulunggaung, kampus dengan 5 fakultas yang salah satunya adalah fakultas favorit masyarakat di sekitar Tulungagung yaitu Fakultas Ekonomi dan Bisnis Islam. Fakultas Ekonomi dan bisnis Islam memiliki 6 jurusan yang dinaungi dengan berbagai fasilitas pendidikan, seperti laboratorium bank mini, laboratorium komputer dan perpustakaan fakultas. Perpustakan merupakan hal yang sangat penting dalam pernanan peningkatan kualitas belajar mengajar. Perpustakaan menjadi sumber referensi mahasiswa untuk mencari ilmu pengetahuan.

Perpustakaan digital merupakan salah satu kebutuhan bagi mahasiswa untuk mengakses ebook, jurnal penelitian bahkan artikel penelitian. Dengan adanya perpustakaan digital mahassiwa mampu mengakses berbagai referensi dari berbagai sumber, guna peningkatan wawasan dan ilmu pengetahuan. Pentingnya peranan dan kemanfaatan dari perpustakaan digital di Fakultas Ekonmi dan Bisnis Islam IAIN Tulungagung ini menjadi topik menarik untuk diteliti. Belum adanya perpustakaan digital dilingkungan Fakultas Ekonomi Dan Bisnis Islam membuat peneliti tertarik melakukan sebuah penelitian tetang analisis penerimaan sistem informasi dan teknologi dalam peningkatan pelayanan digital library di jurusan ekonomi syariah Fakultas Ekonomi Dan Bisnis Islam Institut Agama Islam Negeri Tulungagung mengingat pentingnya pengadaan perpustkaan digital dilingkungan Fakultas Ekonomi Dan Bisnis Islam.

\section{Rumusan Masalah}

Berdasarkan latar belakang masalah di atas, maka rumusan masalah dalam penelitian ini adalah sebagai berikut:

1. Bagaimanakah penerimaan sistem informasi dan teknologi dalam peningkatan pelayanan digital library di jurusan ekonomi syariah Fakultas Ekonomi dan Bisnis Islam Institut Agama Islam Negeri Tulungagung?

2. Bagaimana model penerimaan sistem informasi dan teknologi dalam peningkatan pelayanan digital library di jurusan ekonomi syariah Fakultas Ekonomi dan Bisnis 
Islam Institut Agama Islam Negeri Tulungagung yang dikembangkan mampu meningkatkan kemudahan mahasiswa?

3. Apakah kelemahan-kelemahan yang terdapat pada model penerimaan sistem informasi dan teknologi dalam peningkatan pelayanan digital library di jurusan ekonomi syariah Fakultas Ekonomi dan Bisnis Islam Institut Agama Islam Negeri Tulungagung yang telah dihasilkan?

\section{Tujuan dan Manfaat Penelitian}

Tujuan penelitian mencakup ada isi dan rumusan masalah penelitian. Adapun tujuan dari penelitian ini adalah sebagai berikut:

1. Mengetahui pengaruh penerimaan model sistem informasi dan teknologi dalam peningkatan pelayanan digital library di jurusan ekonomi syariah Fakultas Ekonomi dan Bisnis Islam Institut Agama Islam Negeri Tulungagung.

2. Menghasilkan model penerimaan sistem informasi dan teknologi yang dikembangkan untuk meningkatkan kemudahan pelayanan mahasiswa.

3. Mendiskripsikan kelemahan-kelemahan yang terdapat pada model penerimaan sistem informasi dan teknologi yang telah dihasilkan.

\section{PAPARAN TEORITIS}

\section{Technology Acceptance Model (TAM)}

Thechnology Acceptance Model (TAM) merupakan perluasan dari Theory of Reasoned Action (TRA). Dalam 1 Theory of Reasoned Action (TRA) dijelaskan bahwa niat seseorang terhadap perilaku dibentuk oleh dua faktor utama yaitu sikap terhadap perilaku attitude toward the behavior dan subjective norms. Sedangkan dalam Thechnology Acceptance Model (TAM) ditambahkan dua faktor yang mempengaruhi sebelum sikap itu terbentuk yaitu perceived usefulness dan Perceived Ease of Use.

Technology Acepten Model (TAM) sangat sesuai digunakan untuk menguji penggunaan teknologi informasi di dalam digital library. Persepsi kegunaan (perceived usefulness) merupakan konstruk yang paling banyak dan signifikan dan penting yang mempengaruhi sikap (attitude), niat (behavioral intention) dan perilaku (behaviour) didalam menggunakan teknologi dibandingkan dengan konstruk lainya2.

\footnotetext{
${ }^{1}$ Jogiyanto, Sistem Keperilakuan, (Yogyakarta:Andi,2011), hal. 111

${ }^{2}$ Ibid. Jogiyanto, Sistem Informasi Keperilakuan, (Yogyakarta:Andi,2011), hal. 114 
Pengembangan dalam bidang teknologi menjadikan penelitian lanjutan yang mengembangkan Thechnology Acceptance Model (TAM) dengan menambah variabel eksternal yang digunakan.

\section{Variabel Eksternal}

Variabel eksternal (External Variable) secara langsung akan mempengaruhi persepsi kegunaan dan persepsi kemudahan dari pengguna. Persepsi kemudahan menggunakan dipengaruhi oleh variabel eksternal yang berkenaan dengan karakteristik sistem yang meningkatkan menggunakan teknologi.

Persepsi kegunaan juga dipengaruhi oleh variabel eksternal ini. Contohya, sedang dipertimbangkan dua teknologi, yang keduanya mempunyai kemudahan yang sama dalam pengunaan. Jika salah satu dari kedua teknologi tersebut memberikan kesalahan yang kecil, maka teknologi tersebut dapat dianggap sebagai teknologi yang lebih berguna. menjabarkan pemetaan variabel eksternal yang dikembangkan dalam model TAM yaitu salah satunya adalah kualitas sistem

\section{Persepsi kemudahan menggunakan}

Persepsi kemudahan menggunakan (Perceived Ease of Use) didefinisikan sebagai sejauh mana seseorang percaya bahwa ketika menggunakan teknologi baru akan terbebas dari usaha yang menyulitkan. Konstruk ini juga merupakan suatu kepercayaan seseorang untuk mengambil keputusan dalam menggunakan teknologi. Jika seseorang percaya bahwa teknologi tersebut mudah digunakan, maka orang tersebut akan menggunakannya. Begitu pula sebaliknya, jika seseorang percaya bahwa teknologi tersebut sulit untuk digunakan maka orang tersebut juga tidak akan menggunakannya ${ }^{3}$

Persepsi pengguna terhadap kemudahan dalam menggunakan teknologi dipengaruhi beberapa faktor (Wijaya, 2009). Faktor pertama berfokus pada teknologi itu sendiri misalnya pengalaman pengguna terhadap menggunakan teknologi yang sejenis. Faktor kedua adalah reputasi akan teknologi tersebut yang diperoleh oleh pengguna. Reputasi yang baik yang didengar oleh pengguna akan mendorong keyakinan pengguna akan kemudahan menggunakan teknologi tersebut. Faktor ketiga yang mempengaruhi persepsi pengguna terhadap kemudahan menggunakan teknologi

\footnotetext{
${ }^{3}$ Ibid. Jogiyanto, Sistem Informasi Keperilakuan, (Yogyakarta:Andi,2011) hal. 129
} 
adalah tersedianya mekanisme support yang handal. Mekanisme support yang terpercaya akan membuat pengguna merasa yakin bahwa terdapat mekanisme dukungan yang handal jika kesulitan menggunakan teknologi maka mendorong persepsi pengguna kearah lebih positif.

\section{Persepsi kegunaan}

Persepsi kegunaan (Perceived Usefulness) didefinisikan "sebagai sejauh mana seseorang percaya bahwa menggunakan suatu teknologi akan meningkatkan kinerja serta pekerjaannya ${ }^{4}$. Persepsi kegunaan di sini adalah persepsi pengguna terhadap kegunaan dari teknologi yang digunakan. Konstruk ini juga merupakan suatu kepercayaan seseorang untuk mengambil keputusan dalam menggunakan teknologi. Jika seseorang percaya bahwa teknologi tersebut berguna, maka orang tersebut akan menggunakannya. Begitu pula sebaliknya, jika seseorang percaya bahwa teknologi tersebut tidak berguna bagi dirinya maka orang tersebut juga tidak kan menggunakannya.

\section{Sikap terhadap menggunakan teknologi}

Sikap terhadap menggunakan (Attitude Toward Using) di dalam TAM dikonsepkan sebagai sikap terhadap menggunakan teknologi/ sistem yang berbentuk penerimaan atau penolakan sebagai dampak bila seseorang menggunakannya di dalam pekerjaannya (Wibowo : 2008). Peneliti lain menyatakan bahwa faktor sikap (attitude) sebagai salah satu aspek yang mempengaruhi perilaku individual. Sikap seseorang terdiri atas unsur kognitif / cara pandang (cognitive), afektif (affective), dan komponen-komponen yang berkaitan dengan perilaku (behavioral components) (Nasution : 2006).

\section{a. Niat menggunakan}

Niat menggunakan (Behavioral Intention To Use) adalah suatu keinginan atau niat seseorang untuk melakukan suatu perilaku tertentu ${ }^{5}$. Niat Perilaku (Behavioral Intention To Use) juga merupakan niat seseorang untuk tetap menggunakan suatu teknologi. Tingkat menggunakan sebuah teknologi komputer pada seseorang dapat diprediksi dari sikap perhatian terhadap teknologi tersebut, misalnya keinginan

\footnotetext{
${ }^{4}$ Ibid. Jogiyanto, Sistem Informasi Keperilakuan, (Yogyakarta:Andi,2011), hal. 129

${ }^{5}$ Ibid. Jogiyanto, Sistem Informasi Keperilakuan, (Yogyakarta:Andi,2011), hal. 130 
menambah peripheral pendukung, motivasi untuk tetap menggunakan, serta keinginan untuk memotivasi pengguna lain. Kecenderungan Perilaku ini dipengaruhi oleh Persepsi Kegunaan dan Sikap terhadap Menggunakan (Ibna : 2009).

\section{b. Penggunaan teknologi}

Penggunaan teknologi (Actual Usage) adalah kondisi nyata menggunakan teknologi. Dikonsepkan dalam bentuk pengukuran terhadap frekuensi dan durasi waktu menggunakan teknologi. Seseorang akan puas menggunakan sistem jika mereka meyakini bahwa sistem tersebut mudah digunakan dan akan meningkatkan produktifitas mereka, yang tercermin dari kondisi nyata menggunakan. ${ }^{6}$

\section{Teori Fasilitas Pelayanan pendidikan}

Pengembangan kualitas pelayanan pendidikan memberikan peningkatan dalam suasana belajar mengajar. Fasilitas pelayanan pendidikan memudahkan bagi civitas akademik dalam sebuah lembaga pendidikan. Fasilitas pelayanan pendidikan berupa perpustakaan, laboratorium, ruang kelas dan kondisi gedung. Dengan pemberian fasilitas belajar diharapkan kegiatan belajar anak didik lebih bergairah . Fasilitas adalah sarana dan prasarana yang harus tersedia untuk melancarkan kegiatan pendidikan di sekolah.

Cara Belajar yang Efisien, "untuk belajar yang baik hendaknya tersedia fasilitas belajar yang memadai, antara lain ruang belajar yang baik, perabotan belajar yang tepat, perlengkapan belajar yang efisien". Jadi prinsipnya fasilitas belajar adalah segala sesuatu yang memudahkan untuk belajar. Peralatan belajar yang khusus berkaitan dengan proses belajar mengajar peralatan kantor perlu diperhatikan pemeliharaan dan pengawasan terhadap : a) Ruang belajar, b) Ruang perpustakaan, c) Ruang keterampilan atau praktek.

Those involved in school palnning design see this as an opportunity to enhance academic outcome by creating better learning environments bahwa mereka yang terlibat dalam perencanaan sekolah dan desain, melihat ini sebagai kesempatan untuk meningkatkan hasil akademik dengan menciptakan lingkungan yang lebih baik. Karakteristik individu seperti kecerdasan, gaya kognitif, dan kepribadian memainkan peran penting dalam pembelajaran dan instruksi seperti halnya konteks pembelajaran.

${ }^{6}$ Ibid. Jogiyanto, Sistem Informasi Keperilakuan, (Yogyakarta:Andi,2011) 
Dalam upaya meningkatkan kognisi siswa dan hasil afektif di matematika dan / atau pembelajaran sekolah, psikolog pendidikan dan pendidik matematika, terus mencari untuk variabel (pribadi dan lingkungan) yang dapat dimanipulasi demi keuntungan akademis. Dari semua yang personal dan variabel psikologis yang telah menarik peneliti di bidang pencapaian pendidikan ini, tampaknya motivasi menjadi lebih populer dan memimpin variabel lain. Hal ini didasarkan pada latar belakang inilah yang dipelajari.

Sarana atau fasilitas belajar adalah semua perangkat peralatan, bahan, dan perabot yang secara langsung digunakan dalam proses belajar di sekolah. Dari pengertian tersebut dapat ditarik kesimpulan bahwa fasilitas belajar adalah semua kebutuhan yang diperlukan oleh peserta didik dalam rangka untuk memudahkan, melancarkan, dan menunjang pelaksanaan kegiatan belajar di sekolah. Fasilitas adalah segala sesuatu yang memudahkan anak didik Fasilitas belajar yang mendukung kegiatan belajar peserta didik akan menyebabkan proses belajar mengajar menyenangkan dan memperoleh hasil belajar yang diharapkan. Oleh karena itu fasilitas belajar yang memadai sangat penting demi pencapaian hasil belajar siswa yang memuaskan.

\section{METODE PENELITIAN}

\section{Tempat dan Waktu Penelitian}

Tempat menunjukkan hal penting dalam suatu penelitian sebab di tempat penelitian inilah diperoleh data, informasi, keterangan dan hal-hal yang diperlukan sehubungan dengan kepentingan penelitian. Penelitian ini mengambil lokasi jurusan ekonomi syariah Fakultas Ekonomi dan Bisnis Islam IAIN Tulungagung. Waktu penelitian dimulai bulan agustus 2018 sampai januari 2018.

\section{Sampel dan Data}

Sampel adalah sebagian atau populasi yang diteliti. Pengambilan sampel penelitian harus berhati-hati dan memenuhi aturan pemilihan sampel. Namun demikian, mutu suatu pelayanan jasa transportasi tidak semata-mata ditentukan oleh besarnya sampel, akan tetapi oleh kokohnya dasar-dasar teorinya, rancangan penelitian, dan pelaksanaan serta pengolahannya.

Pengertian sampel adalah bagian dari jumlah dan karakteristik yang dimiliki oleh populasi. Sampel pada penelitian ini mahasiswa ekonomi syariah sejumlah 200 
responden. Penentuan jumlah sampel berdasarkan jumlah sampel maksimal. Penelitian ini diharapkan mampu mengembangan kajian ilmu pengetahuan dibidang teknologi informasi berbasis pendidikan di jurusan ekonomi syariah fakultas bisnis islam IAIN Tulungagung. Sumbangan hasil penelitian ini kedepanya mampu meningkatkan fasilitas layanan pendidikan perguruan tinggi berupa perpustakaan digital berbasis sistem informasi dan teknologi yang mudah digunakan mahasiswa dalam peningkatan layanan pendidikan.

Perpustakaan digital harus merupakan fasilitas yang mudah digunakan dan sangat apllicable, perpustakaan digital harus mampu diterima oleh mahasiswa sebagai bentuk layanan fasilitas pendidikan. Selain itu, pemanfaatan teknologi informasi dalam penggunaan layanan pendidikan harus mampu mengcover apa yang menjadi kenginan pengguna yaitu diharapkan bisa usefullnes (mudah digunakan). Dengan adanya pelayanan perpustakaan digital harapanya mahasiswa mampu mengakses dan melakukan pembelajaran dimanapun dan kapanpun mahasiswa tersebut berada tanpa harus datang kekampus.

\section{HASIL PENELITIAN DAN PEMBAHASAN}

Hasil analisis statistik dengan menggunakan program AMOS versi 21, diperoleh hasil uji statistik yang merupakan uji hubungan kausalitas dari masingmasing variabel penelitian sebagaimana disajikan pada tabel berikut.

\begin{tabular}{|c|c|c|c|c|c|c|c|}
\hline \multicolumn{3}{|c|}{ Variabel } & \multirow{2}{*}{$\begin{array}{r}\begin{array}{r}\text { Hasil } \\
\text { Estimasi }\end{array} \\
1,112\end{array}$} & \multirow{2}{*}{$\begin{array}{l}\text { s.e. } \\
, 180\end{array}$} & \multirow{2}{*}{$\begin{array}{c}c . r . \\
6,175\end{array}$} & \multirow{2}{*}{$\frac{\mathrm{P}}{* * *}$} & \multirow{2}{*}{$\begin{array}{c}\text { Label } \\
\text { par_20 }\end{array}$} \\
\hline Fasilitas & $\rightarrow$ & Kemudahan & & & & & \\
\hline Fasilitas & $\rightarrow$ & Kebermanfaatan & 1,698 & 241 & 7,033 & $* * *$ & par_21 \\
\hline Kebermanfaatan & $\rightarrow$ & Kemudahan & 1,513 & ,215 & 7,026 & $* * *$ & par_22 \\
\hline Kebermanfaatan & $\rightarrow$ & Perilaku &, 972 &, 161 & 6,053 & $* * *$ & par_17 \\
\hline Kemudahan & $\rightarrow$ & Perilaku & ,664 &, 124 & 5,373 & $* * *$ & par_18 \\
\hline Perilaku & $\rightarrow$ & Niat & 1,179 & ,200 & 5,882 & $* * *$ & par_16 \\
\hline Kemudahan & $\rightarrow$ & Niat & 843 & ,129 & 6,528 & $* * *$ & par_14 \\
\hline Kemudahan & $\rightarrow$ & Penggunaan & ,818 &, 169 & 4,831 & $* * *$ & par_12 \\
\hline Niat & $\rightarrow$ & Penggunaan & ,929 &, 154 & 6,017 & $* * *$ & par_11 \\
\hline
\end{tabular}

(Sumber : data diolah 2018) 
Pembahasan hasil uji statistik pengukuran technology acceptance model, berikut ini akan dijelaskan pembahasan hasil pengujian untuk pengaruh masingmasing variabel independen terhadap variabel dependen.

\section{Variabel fasilitas berhubungan positif dengan variabel kemudahan}

Hasil pengujian dapat diketahui bahwa variabel fasilitas mempunyai pengaruh positif terhadap kemudahan dengan critical ratio sebesar 6,175 diperoleh dari koefisien jalur (standardized regression weight estimate) dan tingkat signifikansi critical ratio diatas 1,96 untuk signifikansi 5\%, hal ini menunjukkan bahwa fasilitas digital library berhubungan positif dengan variabel kemudahan didukung oleh data pengukuran model technology acceptance model diterima.

\section{Variabel kebermanfaatan berhubungan positif dengan variabel kemudahan}

Tingkat signifikansi critical ratio diatas 1,96 untuk signifikansi 5\%, dengan critical ratio sebesar 7,026 diperoleh dari koefisien jalur (standardized regression weight estimate) dan, hal ini menunjukkan bahwa kemudahan berhubungan positif dengan variabel kebermanfaatan didukung oleh data, artinya pengukuran model technology acceptance model diterima. Variabel kebermanfaatan berhubungan positif dengan variabel perilaku

Hasil koefisien jalur (standardized regression weight estimate) dengan critical ratio sebesar 6,053 dan tingkat signifikansi critical ratio diatas 1,96 untuk signifikansi 5\%, hal ini menunjukkan bahwa kebermanfaatan berhubungan secara positif dan signifikan terhadap perilaku dan didukung oleh data, artinya pengukuran model technology acceptance model diterima. Variabel kemudahan berhubungan positif dengan variabel perilaku

Berdasarkan pengujian dapat diketahui bahwa variabel kemudahan mempunyai pengaruh positif terhadap variabel perilaku dengan critical ratio sebesar 5,373 diperoleh dari koefisien jalur (standardized regression weight estimate dan tingkat signifikansi critical ratio diatas 1,96 untuk signifikansi 5\%, artinya pengukuran model technology acceptance model diterima. Variabel perilaku berhubungan positif dengan variabel niat

Berdasarkan pengujian dapat diketahui bahwa variabel perilaku berhubungan positif dengan variabel niat dengan critical ratio sebesar 5,882 
diperoleh dari koefisien jalur (standardized regression weight estimate) dan tingkat signifikansi critical ratio diatas 1,96 untuk signifikansi 5\%, artinya perilaku berhubungan positif dengan variabel niat didukung oleh data dan pengukuran model technology acceptance model diterima. Hasil penelitian ini sejalan dengan penelitian yang dilakukan oleh Ammar Khader Mohammad Almasri membuat penelitian tentang penerimaan teknologi menggunakan model TAM. Technology Acceptance Model (TAM) variabel indenpenden dalam penelitian ini (Mobile Readiness, Perceived Interaction, Easy To Use, Usefulness, Attitude to Use) banyak yang memiliki pengaruh signifikan dari variabel independen (the Influence On M-learning Adoption).

\section{Variabel kemudahan berhubungan positif dengan variabel niat}

Berdasarkan pengujian dapat diketahui bahwa variabel kebermanfaatan berhubungan positif dengan variabel niat dengan critical ratio sebesar 6,528 diperoleh dari koefisien jalur (standardized regression weight estimate) dan tingkat signifikansi critical ratio diatas 1,96 untuk signifikansi 5\%, artinya kebermanfaatan berhubungan positif dengan variabel niat didukung oleh data dan pengukuran model technology acceptance model diterima. Variabel kemudahan berhubungan positif dengan variabel penggunaan.

Berdasarkan pengujian dapat diketahui bahwa variabel kebermanfaatan berhubungan positif dengan variabel niat dengan critical ratio sebesar 4,831 diperoleh dari koefisien jalur (standardized regression weight estimate) dan tingkat signifikansi critical ratio diatas 1,96 untuk signifikansi 5\%, artinya perilaku berhubungan positif dengan variabel niat didukung oleh data dan pengukuran model technology acceptance model diterima.

\section{KESIMPULAN}

Analisis koefisien jalur bertujuan untuk melihat signifikansi besaran koefisien path (regression weights estimate) untuk membuktikan pengaruh yang ada. Pada pengujian dua arah (two tailed), hasil pengaruh signifikan jika dengan tingkat signifikansi 0,05 nilai critical ratio > 1,96 dan dengan tingkat signifikansi 0,01 nilai critical ratio $>2,58$. Kesesuaian arah hubungan path dengan arah 
hubungan yang telah dihipotesiskan sebelumnya juga diperhatikan, jika arah hubungan (positif atau negatif) sesuai dengan nilai critical ratio-nya juga memenuhi syarat, maka dapat dikatakan bahwa pengaruh variabel yang diuji memperoleh dukungan yang kuat. Sehingga memungkinkan dengan adanya fasilitas pendidikan maka akan mampu meningkatkan teknologi pembelajaran.

\section{Saran}

Beberapa saran yang diajukan dengan kemungkinan dilakukan pengembangan lebih lanjut adalah sebagai berikut: Menyediakan fasilitas dan sarana prasarana penunjang bagi dosen dan mahasiswa dalam pelayanan perpustakaan digital, pengembangan lebih lanjut disarankan untuk dapat digital library dalam peningkatan fasilitas layanan.

\section{DAFTAR PUSTAKA}

Ammar Khader Mohammad Almasri, The Influence On Mobile Learning Based On Technology Acceptance Model (TAM), Mobile Readiness (Mr) And Perceived Interaction (Pi) For Higher Education Students, US (2016) Review of education, 49 (4), $577-610$

Arikunto, S. 2012. Prosedur Penelitian Suatu Pendekatan Praktek. Jakarta: Rineka Cipta

2012. Prosedur Penelitian Suatu Pendekatan Praktek. Jakarta: Rineka Cipta

Bafadal, Ibrahim. 2004. Manajemen Perlengkapan Sekolah dan Aplikasinya. Jakarta: Bumi Aksara.

Belanchea. D., Casalob. L.V., Carlos \& Flaviana. 2012. Integrating trust and personal values into the Technology Acceptance Model: The case of e-government services adoption. International journal of economic. Vol. 3:65-78

Cristian Weinstein. The physical environment of the school :A reviewof the research. (2016) Review of education, 49 (4), 577-610 
Gapar, Md, Joharl, Md, \& Awalluddin, J.A.A. 2011. The Role Of Technology Acceptance Model In Explaining Effect On E-commerce Application System. International Journal of Managing Information Technology (IJMIT) Vol.3, No.3

Gie, The Liang. 2002. Cara Belajar Yang Efisien. Yogyakarta: Gajah Mada University Press

Ghozali \& Fuad. 2012. Model Persamaan Structural Konsep Dan Aplikasi Dengan Program AMOS 16.0 (edisi I). Semarang: Badan penerbit Universitas Diponegoro. 2012. Structural Equation Modeling (edisi II). Semarang: Badan Penerbit Universitas Diponegoro.

Hart, O. A., Ukoha, O \& Emecheta, B.C . 2012. Integrating TAM and TOE Frameworks and Expanding their Characteristic Constructs for E-commerce Adoption by SMEs. International journal of Proceedings of Informing Science \& IT Education Conference. Vol. 2:15-28

Hsiaoa, C.H \& Yanga, C. 2011. The intellectual development of the technology acceptance model: A co-citation analysis. International Journal Of Information Management. Vol.31:128-136

Imam Ghozali dan Fuad. 2008. Structural Equation Modeling. Semarang: Badan Penerbit Universitas Diponegoro.

Jogiyanto, HM. 2008. Model Kesuksesan Sistem Teknologi Informasi. Yogyakarta: Andi. 2013. Sistem Teknologi dan Informasi Bisnis Pendekatan Strategis. Yogyakarta: Andi.

Marita, Tin. 2007. Membentuk softskill Akuntansi melalui Effective Team Building McGrath's Model dalam Ruang Kelas: Sebuah Aplikasi McGrath's Model, Makalah Simposium Nasional Akuntansi X, Makasar.

Nofiyanti, Endah. 2011. "Pengaruh Fasilitas Belajar terhadap Hasil Belajar Mata Pelajaran Melakukan Prosedur Administrasi Melalui Proses Komunikasi 
Guru Pada Siswa Kelas XI Jurusan Administrasi Perkantoran SMK Tamansiswa Kudus”. Skripsi. Semarang: Fakultas Ekonomi UNNES.

Rehman, S \& Coughlan, J. 2011. Building Trust of Mobile Users and their Adoption of M-Commerce. International journal of Engineering and Technology. Vol:5

Sabir, R.I., Shahnawaz, M., Zaidi, B., Kamil, H \& Akhtar, N. 2014. Adoption of Ecommerce amongst Pakistani Consumers A Case of Mobile Banking. International journal of management and bussines reseacrh. Vol. 1

Sari, Widiyani Puspita. 2005. "Pengaruh Fasilitas Belajar terhadap Hasil Belajar Komputer Siswa Kelas II Program Keahlian Sekretaris di SMK Batik 1 Surakarta”. Skripsi. Semarang: Fakultas Ilmu Sosial UNNES.

Saloman, D \& Salman, R. 2013. E-commerce Propagation in The Middle East Economies: an Application of a Revised Technology Acceptance Model. International journal of economic. Vol. 5: 157-177Schneider, Mark. 2002. Do school facilities affect Academic Outcomes. Natioanal Clearinghouse For Educational Facilities.

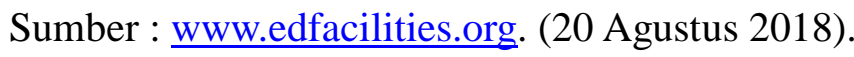

Sugiyono. 2013. Metode Penelitian Pendidikan Pendekatan Kuantitatif, Kualitatif dan R\&D. Bandung. Alfabeta.

Smith, T.J. 2010. Senior Citizens and E-commerce Websites: The Role of Perceived Usefulness, Perceived Ease of Use, and Web Site Usability. the International Journal of an Emerging Transdiscipline. Vol. 11: 45-62

Thong, James Y.L. \& Xin Xu. 2017. Unified Theory of Acceptance and Use of Technology: A Synthesis and the Road Ahead. (University of Arkansa, Journal of the Asosiation for Information System, 2 (2):116-145

Tung, Lo Choi. 2011. The Impact of Entrepreneurship Education on Entrepreneurial Intention of Engineering Students. City University of Hongkong: Run Run Shaw Library.

Yeh, Y.S \& Li, Y.M. 2009. Building trust in m-commerce: contributions from quality and satisfaction. Emerald international jurnal. Vol.33:1066-108. 
